Katrin Martens, Anke Wolff, Markus Hanisch

\title{
Understanding Social Innovation Processes in Rural Areas: Empirical Evidence from Social Enterprises in Germany
}

2020 | Journal Article | Accepted Manuscript (Postprint)

available at https://doi.org/10.18452/22931

licensed under CC BY-NC 4.0

Final version published as:

Katrin Martens, Anke Wolff, Markus Hanisch: "Understanding Social Innovation Processes in Rural Areas: Empirical Evidence from Social Enterprises in Germany". In: Social Enterprise Journal, 2020. DOI: 10.1108/SEJ-12-2019-0093

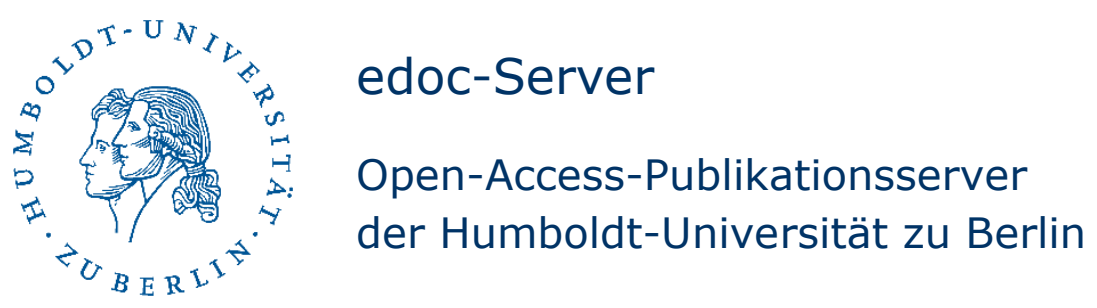




\title{
Understanding Social Innovation Processes in Rural Areas:
}

\section{Empirical Evidence from Social Enterprises in Germany}

\author{
Martens, Katrin ${ }^{\text {a; }}$ Wolff, Anke ${ }^{\text {b }}$ Hanisch, Markus ${ }^{\mathrm{c}}$ \\ ${ }^{a}$ Department of Agricultural Economics, Humboldt-Universität zu Berlin, Berlin, Germany, and Leibniz Centre \\ for Agricultural Landscape Research, Müncheberg, Germany, Katrin.Martens@hu-berlin.de \\ ${ }^{b}$ Department of Agricultural Economics, Humboldt-Universität zu Berlin, Berlin, Germany \\ ${ }^{c}$ Centre for Rural Development (SLE), Humboldt-Universität zu Berlin, Berlin, Germany
}

\begin{abstract}
Purpose Against the background of increasing infrastructure loss in many rural areas, this study aims to contribute conceptually and empirically towards a better understanding of rural innovation processes related to the provision of public goods.
\end{abstract}

Approach The nationally-focused understanding of innovation processes leads the debate on rural development into a dilemma that we seek to sidestep via the concept of social innovation. Community cooperatives - a type of social enterprise that has increasingly emerged in rural areas of Germany in the last decade - offer the opportunity to examine social innovation processes. Our cross-case study reveals the broad range of activities in which such cooperatives are active and analyses their social innovation processes.

Findings The study shows that the social innovation governance framework enables examination of social innovation processes. Although macro-level policy has appeared to be an important instrument for financing social innovation, public actors at the micro-level seem barely able to initiate social innovation processes unless they are also private actors and, therefore, can pursue additional incentives. The social innovations studied here seem to differ in terms of their actor constellations and 
resource-allocation patterns, depending on whether they are concerned with the establishment or maintenance of local infrastructure. What they have in common, however, is the initiation of formalised collective-action processes that serve to legitimise social innovation.

Originality By applying an analytical framework that is new to the literature on social innovation, the study provides insight into the activities and decision-making processes of actors involved in social innovation in rural areas. In this context, community cooperatives have rarely been studied as an interface between public, private and civil society actors or as a platform for mobilising human, social and financial capital.

Keywords collective action, cooperatives, governance, innovation research, public-good provision, rural development 


\section{Introduction}

Governments are struggling to sustainably improve living conditions in rural areas. While in the European Union new member states are slowly catching up with the old ones, the "intranational differences between growing and stagnating regions have increased" (Ehrlich et al., 2012). Local governments in rural areas are often confronted with declining infrastructure, aging populations, outmigration into urban areas and high debt, leading to vicious circles of frustration within civil society and most likely declining confidence in democracy (Kluth, 2019; Copus, 2011). Despite decades of public funding, living conditions in rural areas in many regions have tended to deteriorate, calling into question the public sector's role in rural development (Neumeier, 2017; Bock, 2016).

Despite widespread consensus in the academic literature that innovation is key to economic development on both micro (organisational) and macro (national) scales (Shearmur et al., 2018), there is little agreement in research and policy-making regarding how innovation can be triggered in regions outside urbanised areas and by whom (Bock, 2016; Dargan and Shucksmith, 2008) or even whether innovation policy might trigger rural development at all (Steiner and Farmer, 2018; Neumeier, 2017).

Recent studies claiming that rural areas require a different understanding of innovation and, in turn, different innovation policies to address rural development, advocate the concept of social innovation (Nicholls and Dees, 2015; Dargan and Shucksmith, 2008; Moulaert and Sekia, 2003). However, only a few primarily theoretical discussions related to the potential of social innovation for rural development have been conducted, revealing a lack of empirical studies for evaluating the collective-action capacities of rural actors (Steiner and Teasdale, 2019; Neumeier, 2017; Bock, 2016; Bock, 2012). To gain deeper understanding of changing 
governance processes in social innovation at the micro-level, we agree with Borrás and Edler (2014) that this requires examining "the opportunity structure and capable agents in a system, the instrumentation [...] and the legitimacy and acceptance of change." Consequently, our study takes a processual perspective and examines the following questions: First, who initiates and what motivates social innovation processes? Second, what instruments can enable social innovation? Third, how are social innovation legitimised?

To address these questions, section 2 summarises the current innovation literature and queries its applicability to the study of innovation within rural development. In section 3 , the concept of social innovation as a means of integrating rural development into the innovation literature is introduced and the social innovation literature is further expanded by the inclusion of Borrás and Edler (2014) three-pillar concept of governing change. Empirically, we focus on community cooperatives as one platform for the study of social innovation processes in rural areas. Finally, we present a cross-case analysis of 14 community cooperatives from different fields to deepen understanding of rural social innovation processes and discuss our research questions.

\section{Identifying the dilemmas of rural development within innovation research contexts}

What is known about innovation dynamics often reflects what has been called an urban bias (Shearmur, 2012). This is apparent from the measurements and indicators used to compare the innovation performance of different regions, such as the Regional Innovation Scoreboard (Hollanders et al., 2019), which analyses performance indicators, including numbers of patent applications and publication rates of scientific articles, which do not correspond to rural-area 
characteristics (Kozłowski, 2015) nor generally improve living conditions in rural areas. From this point of view, actors living in less populated areas, which we define as rural areas (BBSR, 2019), generate less innovation than actors living in densely populated areas. Consequently, innovation research and policy at the micro and macro levels are largely derived from concepts and empirical studies produced and implemented in urban areas (Shearmur et al., 2018; Moulaert and Sekia, 2003).

Decades of innovation research have left many open questions regarding rural development and appropriate innovation policies to support it. Rural areas with low population density have different characteristics than urban areas. Further, there is not only a lack of research on whether these characteristics promote innovation capacity or not; some studies also see rural areas as being the opposite of innovation centres, creating a negative picture of them as disadvantaged areas, which is one reason explaining the dilemmas of rural development (Eder, 2019; Ehrlich et al., 2012; Lang, 2012). As researchers today argue that national innovation policies may create not only economic development but also inequality between regions (Shearmur et al., 2018), the question is whether public actors understand the difference between the goal of triggering economic growth and that of improving and maintaining living conditions for people in rural areas (Moulaert and Sekia, 2003).

In the present study, the dilemmas of rural development are investigated along two dimensions, both of which reveal a governance gap. First, governments and many studies do not distinguish sufficiently between instruments to promote rural development and those promoting national innovation (Shearmur et al., 2018). Dargan and Shucksmith (2008), for example, noted that the implementation of innovation policies in rural areas, guided by certain ideas regarding innovation in such contexts, often encounter a lack of understanding among local actors. Secondly, clear incentive structures are lacking, especially for infrastructure 
projects in rural communities, so it is typically not clear who is responsible for innovations to improve living conditions in rural areas (Rodriguez-Pose and Di Cataldo, 2015; Nicholls and Dees, 2015).

\section{The social innovation governance framework}

Rural-development dilemmas do not necessarily mean that rural actors are unable to innovate. Innovation targeting rural development does take place in rural areas, but research has not yet provided satisfactory concepts for analysing these processes (Beetz, 2008; Keim, 2006). In this context, the term social innovation - defined as "new ideas that meet social needs, create social relations and form new collaborations" (EU, 2019) - bears mentioning, as it continues to gain importance on the political agenda (EU, 2014; Borzaga and Bodini, 2012). This concept spotlights collective-creation processes in which actors are learning, inventing and creating new rules for interaction (Howaldt and Schwarz, 2010). While Mumford (2002) stresses the purpose of social innovation as the achievement of common goals, Moulaert and Sekia (2003) and Bock (2016) are more specific, defining it as leading to social change and empowerment.

In the past, innovation research has largely ignored the concept of social innovation (van der Have and Rubalcaba, 2016). For some, it remains unclear whether social innovation is a concept that stands alongside others, such as technological innovation, or embodies a completely new understanding of innovation (Marques et al., 2018; Nicholls and Dees, 2015). While Mulgan (2006) assumes that social innovation will dominate technological innovation in the future, others criticize the concept as too blurred, threatening to become a new buzzword that everyone can agree on, but no one knows what it means (van der Have and Rubalcaba, 2016; Pol and Ville, 2009). Although the concept of social innovation suggests that innovation 
processes must be undertaken by collectives and not individuals (Neumeier, 2012), it is not clear who should or can steer such processes in rural areas. According to Bock (2016), the increasing use of the term in politics can also be understood as an attempt by the public sector to shift responsibility for rural development to civil society, selling it as a "new opportunity for citizens' initiatives" that become a panacea for moving rural development forward. Another unresolved controversy is whether social innovation, due to its endogenous nature, can be promoted through policies at all (Neumeier, 2017; Butkevičienè, 2009).

Responding to such criticism, researchers are becoming increasingly specific in their studies. Nicholls and Dees (2015) propose a concept that distinguishes between the processes and outcomes of social innovation as well as differentiating between analyses at the micro, meso or macro scales. While the outcome perspective is preferred by policymakers, such as by the European Union (van der Have and Rubalcaba, 2016), some scholars are examining the process dimension (Neumeier, 2017), while others are just beginning to collect empirical knowledge (Noack and Federwisch, 2019; Figueiredo and Franco, 2018). Neumeier (2017) has formulated four criteria for identifying successful social innovations: they should be "innovative in terms of user, context or application" but also "more effective than existing alternatives," "offer long-term solutions" and "be adopted beyond the original group/network that developed them."

We propose that, unlike many other concepts, social innovation enables the study of innovation in rural-development contexts. First, it acknowledges the importance of new or other actors in the innovation process (Bock, 2012), whereas innovation models mostly focus on R\&D departments, private start-ups or universities as innovation actors. Second, the social innovation approach has a strong component of collective action, which, in the absence of markets, appears to be an essential resource for promoting innovation in rural areas (Phillips 
et al., 2015). While this does not answer the question regarding who should be responsible for innovation in support of rural development, it underlines that innovation might also be a community task. Third, social innovation has a normative component, namely the goal of creating social benefits in local communities (Nicholls and Dees, 2015). Overall, the concept of social innovation can facilitate innovation research by bringing it closer to typical ruraldevelopment contexts and offering potential solutions for their dilemmas.

\section{Agent and opportunity structures}

Who initiates and what motivates social innovation processes?

\section{Instrumentation}

What instruments can enable social innovation?

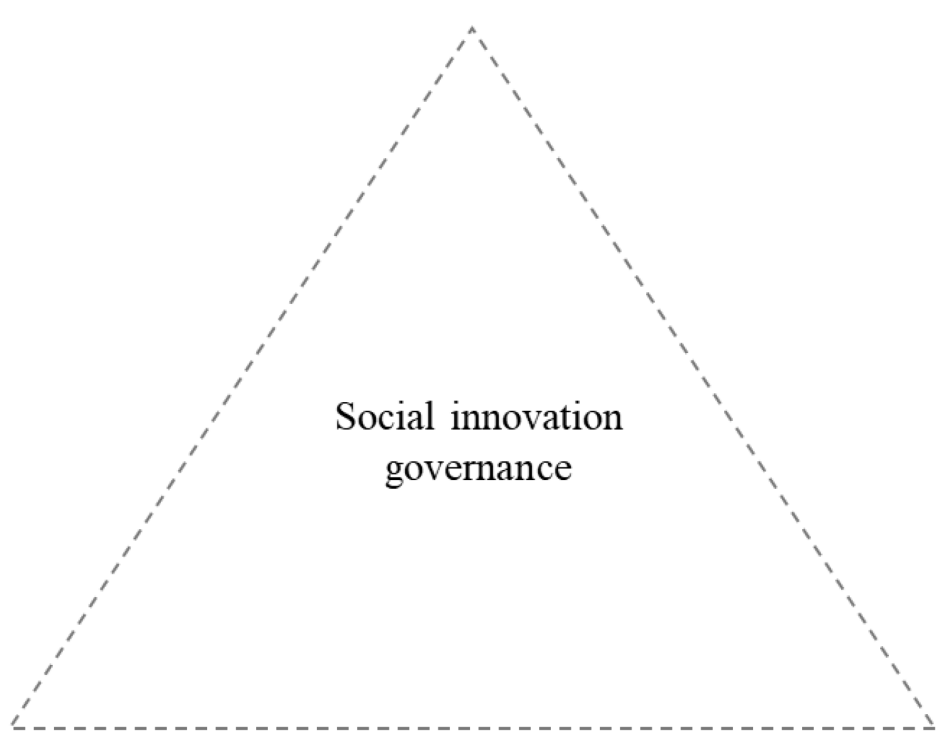

\section{Legitimacy}

How are social innovation legitimised?

Figure 1 Analytical framework of social innovation governance (adapted from Borrás and Edler J. (2014))

As the dilemmas of rural development show, there is not only a lack of concepts for describing innovation in rural communities but also a need for analytical frameworks for expanding knowledge in the field of social innovation research. To contribute to the literature on social innovation, we introduce the concept of governance of change. Whereas Borrás and Edler 
(2014) originally focused on generally improving knowledge in the socio-technical innovation literature by incorporating three pillars - agent and opportunity structures, instruments and legitimacy - into their conceptual framework ${ }^{1}$, we argue that focusing on these three pillars can also provide an important analytical lens for social innovation research in rural areas (Figure 1). As Richter (2018), Borrás and Edler (2014) and Lang and Roessl (2011) argue, governance is exceedingly important for understanding collective action. Regarding the present context, governance of change is defined as "interaction and coordination of actors to regulate issues of societal interest" (Borrás and Edler, 2014).

The three pillars are defined as follows: The first pillar combines capable agents and opportunity structures into one dimension, since opportunities do not generate change by itself but, rather, must be recognised, accepted and realised by capable agents (Borrás and Edler, 2014). The second pillar - instruments - is related to questions regarding the "how" of governance. Borrás and Edler (2014) define governance instruments as mechanisms that drive collective action to achieve specific goals, including both policy instruments and "instruments of social actors," depending on who designs them. The third pillar - legitimacy - is associated with degrees of acceptance along the actor chains that comprise social innovation processes and whether relevant communities support and participate within them (Borrás and Edler, 2014).

\footnotetext{
${ }^{1}$ Borrás and Edler (2014) presented this analytical framework in 2014 in their book "The Governance of Socio-Technical Systems: Explaining Change." They argued that these "three pillars together provide a comprehensive view of the central governance-related research question" and have never before been analysed together, although each of these pillars can be separately found in the literature.
} 


\section{Methods}

4.1 The notion of the community cooperative for the study of social innovation governance

Globally, the cooperative business model has a long history in rural areas. Defined as "autonomous associations of people who voluntarily join together to meet their common economic, social and cultural needs and aspirations through a jointly managed and democratically controlled enterprise" (ICA, 2019), cooperatives are a traditional concept combining elements of co-ownership and participation with a business model, encompassing risk and financial bundling mechanisms. Agricultural cooperatives are considered to link rural actors with markets and knowledge networks (Münkner, 2012; Birchall and Simmons, 2009; Bonus, 1986).

While traditional cooperatives have generally been in decline worldwide in recent years (Huybrechts and Mertens, 2014), since the 1970s there has been an increase in the number of social enterprises, such as social or community cooperatives, which, because of their control mechanisms and democratic principles, are similar to traditional cooperatives but are not conceptualized to meet the needs of their members but, rather, pursue general social or environmental objectives (Defourny and Nyssens, 2016; Somerville, 2007). Such social enterprises $^{2}$ are, therefore, considered particularly interesting within the context of social

\footnotetext{
${ }^{2}$ Defourny and Nyssens (2016) refer to these social enterprises as "social cooperative-like enterprises," referring to the fact that not all countries have a legal framework for these cooperatives or that there are groups that they refer to as cooperatives for other reasons.
} 
innovation research, since they not only practice collective action but also seek to fulfil the social needs of a wider community.

Although no generally accepted and clear definition of the term community cooperative exists yet (Somerville and McElwee, 2011; Lang, 2012; Lang and Roessl, 2011), the term is not new and has primarily been used to describe a social cooperative that operates in a particular geographic place, such as a rural municipality (Storey, 1980). Community cooperatives are found in a number of areas, with Lang and Roessl (2011) noting, for example, that in Austria and Germany they provide services and amenities in neighborhoods, such as shops, recreational facilities, or cafes. Meanwhile, with the involvement of experts from different European countries, Huybrechts and Mertens (2014) discuss the role of renewable energy cooperatives as community cooperatives, due to their positive collective externalities, and Lorendahl (1996) describes the development of community cooperatives in Sweden, which operate in areas traditionally belonging to the public sector, such as child and health care.

Focusing on community cooperatives through an innovation lens, Somerville and McElwee (2011) propose that, in contrast to traditional cooperatives, community cooperatives have loose social networks, which can make it easier for them to bridge to external stakeholder knowledge. In addition, Lang and Roessl (2011) point out the ability of community cooperatives to allocate various resources. Thus, we hold that, due to their past endeavours in rural areas, their principle of collective action and pursuit of social objectives, community cooperatives are suited for investigating social innovation governance in rural areas.

\subsection{Case background and context}

Germany is a country with cooperative organisations covering all economic sectors and regions. Today there are around 6,000 cooperatives in Germany with 22 million members, 
making cooperatives the country's largest business model in terms of membership (DGRV, 2019).

Traditionally, German cooperatives catered to the typical service needs of rural areas: agricultural supply and storage, rural financial services, processing and marketing of agricultural products. With increasing agricultural productivity and an overall shrinking role for agriculture in the German economy, structural change in agriculture and rural finance became widespread (OECD, 2014; Wieg, 2014). Although the total number of cooperatives declined, their size increased. Furthermore, beginning in the 1990s, the number of newly founded cooperatives fell continuously to around 30 per year (DGRV, 2019; Haunstein and Thürling, 2017).

In 2006, Germany reformed its cooperative law, which now allowed the establishment of cooperatives that pursue not only economic but also cultural and social objectives. Furthermore, the government programme for the promotion of renewable energies seemed to increase the number of cooperatives. Between 2006 and 2018, some 2,400 cooperatives were founded in various sectors - the largest increase since the 1960s (Thürling, 2019; Haunstein and Thürling, 2017).

\subsection{Case selection and analysis}

Taking a qualitative and explorative approach, the present study seeks to gain new empirical evidence for understanding social innovation processes by analysing community cooperatives. Prior to conducting our field study, our research design was reviewed through interviews with two experts from two different cooperative umbrella organisations in Germany and one expert with a rural development policy background in Germany. Responding to recent calls in the social innovation and social enterprise literature for more comparative empirical studies 
(Steiner and Teasdale, 2019; Bauwens and Defourny, 2017; Mazzei, 2017), our aim was to compare different projects in order to identify social innovation process patterns that go beyond individual enterprises.

In this context, however, it was considered important to keep certain political and legal frameworks the same to allow for better comparability between cases. Therefore, only registered cooperatives in Germany were selected for this study. Selection of rural regions was made according to the definition of the Federal Institute for Research on Building, Urban Affairs and Spatial Development (BBSR, 2019) ${ }^{3}$. Applying this definition, we examined the German new cooperative statistics (DZ Bank, 2017). The analysis showed that more than 800 of the 2,400 newly founded cooperatives have been established in rural areas since the amendment of the law in 2006. In order to avoid too much heterogeneity in terms of widely different landscapes and policies, four federal states, all of which are predominantly rural, were selected: Brandenburg, Schleswig-Holstein, Mecklenburg-Western Pomerania, and Lower Saxony. This reduced the number of potential case studies from 800 to around 200. In addition, a media analysis was carried out by examining local newspaper articles and the internet presence of cooperatives to ensure that the cases selected were regionally based and followed the interest of not only their members, but of a wider community. Further, cases were selected by applying Neumeier criteria for successful social innovation (Neumeier, 2017) ${ }^{4}$. Primary data were collected on four different excursions between August 2018 and December 2018. According to the Grounded Theory approach, the data were reviewed after each trip and new cases were selected until the research questions were satisfactorily answered

\footnotetext{
${ }^{3}$ Except for one case, which, by definition, belongs to an urban area due to an agglomeration of a nearby city. The cooperative lies outside this agglomeration in a very remote area.

${ }^{4}$ According to the definition in 3
} 
(Flick, 2017). Finally, 14 community cooperatives in 14 different rural municipalities were selected for the study (see Table 1). Because of the wide range of community cooperatives involved in rural development, it was deemed necessary to represent this range while also examining similar types to see how similar challenges are dealt with in different communities with different institutional settings and histories (Somerville and McElwee, 2011).

Some community cooperatives were easy to identify as such, while others were more difficult. For example, the wind cooperative (case 14) could be characterised as working primarily for the mutual interest of its members because it generates electricity without making it available to the community, whereas the photovoltaic cooperative (case 13) generates its electricity to supply public buildings in the community for public use (Bauwens and Defourny, 2017). However, because of the positive economic impacts they provide to the rural municipalities in terms of tax income, job and knowledge creation, as well as environmental impacts, both were defined as community cooperatives in line with Huybrechts and Mertens (2014) and as social innovations (Hanisch and Fairbairn, 2017).

Semi-structured interviews were conducted with one or two members of each community cooperative, usually board members and project initiators, who are considered most knowledgeable about the processes involved as confirmed by previously interviewed experts. With participant consent, all interviews were recorded and transcribed for further analysis, using MAXQDA software for transcripts and coding. 
Table 1 Characteristics of German case-study cooperatives

\begin{tabular}{|c|c|c|c|c|c|}
\hline No. & Description & Cooperative business & Foundation & Members & $\begin{array}{l}\text { Member fee } \\
(€)\end{array}$ \\
\hline 1 & $\begin{array}{l}\text { Community centre, village } \\
\text { shop }\end{array}$ & $\begin{array}{l}\text { Purchase and restoration of privately owned pub. Administration and } \\
\text { leasing of community centre to citizens and establishment of village } \\
\text { shop. }\end{array}$ & 2012 & 300 & 100 \\
\hline 2 & $\begin{array}{l}\text { Community house, pub, } \\
\text { hotel }\end{array}$ & $\begin{array}{l}\text { Purchase and restoration of two privately owned buildings. Building } \\
\text { management, with restaurant and hotel run by private tenant. }\end{array}$ & 2016 & 100 & 2,500 \\
\hline 3 & Community house, café & $\begin{array}{l}\text { Renting a building renovated for this purpose by a private owner. } \\
\text { Operation and organisation of café and events for village. }\end{array}$ & 2014 & 100 & 100 \\
\hline 4 & Community swimming pool & Management and operation of public swimming pool. & 2009 & 1,016 & 50 \\
\hline 5 & Community swimming pool & Management and operation of public swimming pool. & 2012 & 1,100 & 50 \\
\hline 6 & $\begin{array}{l}\text { Elderly care, community } \\
\text { house }\end{array}$ & $\begin{array}{l}\text { Initiation and administration of a nursing home and common room for } \\
\text { citizens. Nursing home managed by private tenant. }\end{array}$ & 2013 & 100 & 500 \\
\hline 7 & E-mobility & $\begin{array}{l}\text { Negotiations with e-car manufacturers and marketing of various models } \\
\text { to customers. }\end{array}$ & 2010 & 430 & $\begin{array}{l}200+50 \text { per } \\
\text { year }\end{array}$ \\
\hline 8 & E-mobility, photovoltaics & Development of charging infrastructure for e-cars. & 2013 & 50 & 250 \\
\hline 9 & Freshwater supply & Purchase, maintenance and management of fresh water supply. & 2003 & 71 & 500 \\
\hline 10 & Local heating grid & Initiation and operation of local heating network. & 2012 & 60 & 2,500 \\
\hline 11 & Local heating grid & Initiation and operation of local heating network. & 2011 & 600 & 400 \\
\hline 12 & Multi-generation housing & Initiation of construction and leasing of multi-generation housing. & 2009 & 74 & 500 \\
\hline 13 & Photovoltaics & Construction and management of three photovoltaic plants. & 2014 & 50 & 500 \\
\hline 14 & Wind power & Initiation and management of wind turbine. & 2015 & 85 & 2,500 \\
\hline
\end{tabular}


To enhance understanding of rural social innovation processes involving collective action, our questionnaire consisted of open questions regarding the motivations, perceptions, and roles of people in the process. It was divided into four categories: general information about the cooperative, its founding process, current status, and future plans. These categories included specific questions on the roles of the private and public sectors and civil society. Throughout the survey and its evaluation, a coding guide was gradually developed based on Grounded Theory (Flick 2017) with information that appeared repeatedly in the interviews being coded according to the coding guide in Table 2. As Schumpeter (1934) points out, innovation can be understood as a new combination of different resources such as human, social and financial capital (Brunie, 2009; Schultz, 1961). Information that appeared repeatedly in the interviews was coded. As these were qualitative interviews, exact classification was not always straightforward, so the categories of social and human capital were merged.

Table 2 Codes and definitions for actors and resources developed during post-interview analysis

\begin{tabular}{ll}
\multicolumn{2}{l}{ Actors in the social-innovation process } \\
\hline Public actors & Village heads, politicians \\
\hline Private actors & Own enterprises that profit from cooperative projects \\
\hline Civil Society & $\begin{array}{l}\text { People living in the community, engaging in projects without } \\
\text { financial incentives }\end{array}$ \\
\hline Resource allocation in the social innovation process \\
\hline Initiation & Actors initiating social innovation processes \\
\hline Human and & $\begin{array}{l}\text { Actor supporting social innovation process by sharing their } \\
\text { social capital }\end{array}$ \\
& $\begin{array}{l}\text { experience, knowledge and connecting people with each other, } \\
\text { sharing their networks }\end{array}$ \\
\hline Financial capital & Actors supporting social innovation processes with financial \\
& resources
\end{tabular}




\section{Results and discussion}

While the promotion of innovation by governments is a popular strategy for strengthening economic growth, the decline of local infrastructure in many rural areas indicates that national innovation strategies do not necessarily lead to rural development. In this context, the concept of social innovation has recently been promoted, serving as a basis for the present empirical study. Social innovation focuses on collective action to satisfy social needs, which we have investigated via community cooperatives established in Germany in recent years (Table 1). The results of our cross-case analysis are presented in Table 3, and further presented along the research questions.

\subsection{Applying the social innovation governance framework}

As explained above, in this paper we apply the framework proposed by Borrás and Edler (2014), which intends to contribute to the analysis of the "central 'governance' related research question of system change" (Borrás and Edler, 2014), by identifying "who and what drives change," "how change is influenced" and "why it is accepted." As mentioned in the literature review, this framework is considered appropriate for this study context, as it enables examination of the dilemmas of rural development, which are defined in this study along two dimensions. First, policies intended to trigger innovation are usually not sufficiently separated into those aimed at national economic growth and those seeking to provide public services in rural communities (Bock, 2016; Moulaert and Sekia, 2003), revealing a gap with respect to the question of "how change is influenced". Secondly, the incentive structures and responsibilities for innovation in rural areas are largely unclear (Dargan and Shucksmith, 2008), indicating a need to examine who and what drives change in rural social innovation processes. Finally, whether social innovations are accepted is seen as an important factor for 
fostering rural development, because they are likely to take over tasks related to the public interest and, hence, should be democratically legitimised in some way.

\subsubsection{Who initiates and what motivates social innovation processes?}

Given the gaps in the innovation literature and absence of empirical knowledge regarding who is capable of initiating social innovation processes in rural areas, our interviews focused especially on this subject. Private-sector, public, and civil-society actors were analysed separately, as detailed in Table 3 and summarised in Figure 2. Since it became clear from the initial interviews that one person can embody several positions, detailed definitions for each role were formulated (see Table 2).
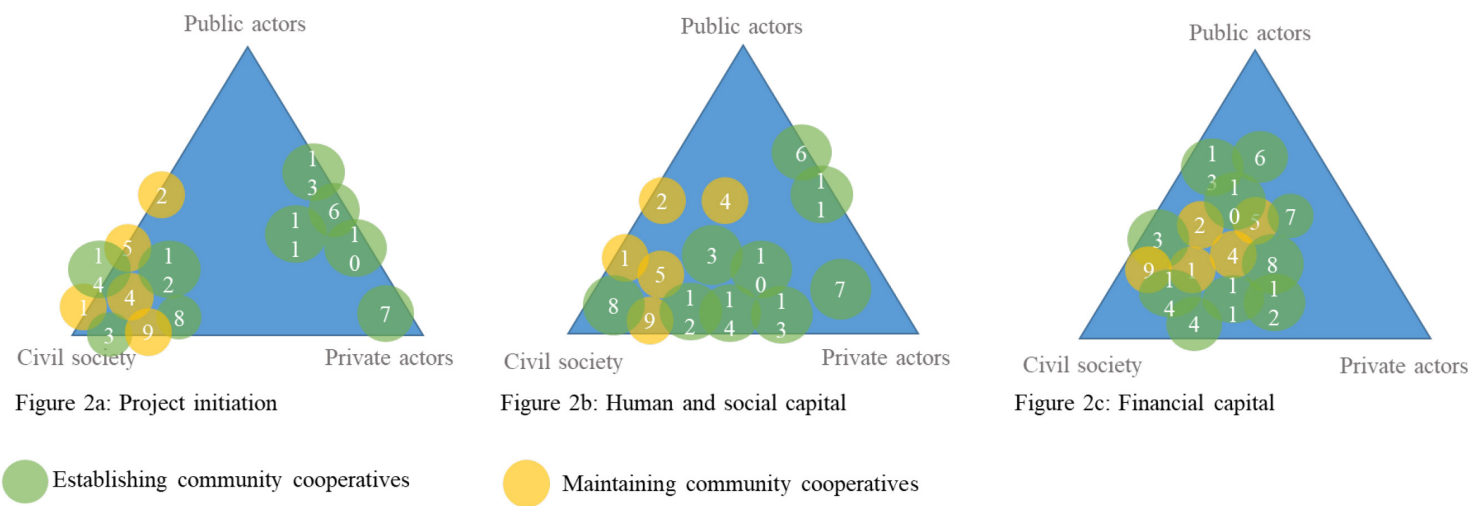

Figure 2 Interaction between actor groups involved in community cooperatives on the local scale (numbers refer to cases presented in tables 1 and 3)

Our case-study comparison shows that, on its own, local government typically lacks the ability to initiate social innovation processes (see Figure 2a). Depending on the relationships between different actors, local government has even been described as a burden that functions inefficiently. To illustrate this, one interview respondent explained that he was able to implement the project he was involved in despite the local government, while another replied that his cooperative advised the local government on how to apply for funding. Nevertheless, 
most community cooperative representatives agreed that, from the outset, it was important to integrate local government into their projects, as they had to work together with and rely on government support. Generally, the public sector is considered an important actor in innovation policy (Eder, 2019), but its role in social innovation appears to be diverse and requires differentiation into different scales.

According to Figure 2a, the private sector appears to be more capable of initiating social innovation than the public sector but less so than civil society. Some projects were most likely initiated by the private sector because the involved actors benefited from them and were able to improve their livelihoods. Our results suggest that private actors in rural areas who are involved in activities especially connected to rural areas are also more likely to develop ideas relevant to their own areas of business. They also have additional knowledge channels that could trigger entrepreneurship. Case 10 illustrates this: hearing about the possibility of a biogas plant that could also provide heat for the community might be more likely if an entrepreneur is working in the agricultural sector or already owns a biogas plant. Similar patterns were observed in six of the 14 cases. This would mean that participatory governance and traditional entrepreneurship, in which individuals become creative for their own benefit, as defined by Schumpeter, are not mutually exclusive, as Richter (2018) proposes. Richter (2018) examines different types of social enterprises and distinguishes between the behaviour of internal and external stakeholders when it comes to generating ideas within the established company, from which he concludes that "the innovative power of the company no longer depends on the innovative spirit of an individual entrepreneur" (Richter, 2018). However, if we look at the entire social innovation process in a rural community - which in the present study starts with the process of initial idea generation and includes the establishment of a cooperative up to the successful implementation of its project(s) - it seems that idea generation usually does come from one person, often a private actor, who may have additional incentives 
to pass that idea on to a larger group, which then initiates the participatory governance process that is crucial to designating the innovation as a social one.

Concerning civil society in rural communities, our results suggest that most social innovations were initiated, managed and financed by local civil society actors, as shown in Figure 2, underlining the strongly endogenous nature of rural social innovation processes (Bock, 2016), on one hand, and the need to integrate civil society into rural development policies on the other. However, initiating projects does not directly lead to successful social innovation, as only two civil-society-led projects succeeded in managing the process alone, without strong links to local government or the private sector. These empirical results seem to support claims that "the most creative action takes place at the borders between sectors" (Murray et al., 2010).

The case studies investigated here indicate that a variety of opportunity structures affect actor constellations, processes, and outputs. In the sample, two different types of community cooperatives were identified as resulting from different opportunity structures: 1) projects aimed at building new infrastructure, such as nursing homes for the elderly, renewable energy projects, or multi-generational housing, and 2) projects aimed at maintaining existing infrastructure, such as swimming pools and community pubs. Projects initiated to maintain infrastructure were often initiated due to local emergencies that led to high demand for social innovation (Table 3). Meanwhile, social innovation leading to the establishment of new infrastructure tends to have a different kind of driver, referred to as an opportunity-oriented social innovation, which is directly linked to instruments of social innovation governance and, therefore, referred to in 5.1.2.

Focusing on these different opportunity structures and linking them to capable actors indicates that private actors seem to be more capable of initiating opportunity-driven social innovation 
but are more likely to support demand-driven social innovation financially or with human and social capital (Figure 2). Depending on the nature of the required social innovation, different actors may steer the process. In the opportunity-driven processes, private and public actors who managed to integrate actors from civil society usually initiated the project. Demand-led projects were all initiated by civil society, which in turn integrated actors from the private and public sectors. These findings are likely to be important when developing policies aimed at social innovation in rural areas, as they can help in creating different incentives for different actors and potentially moving significantly closer to solving rural development dilemmas. By applying the social innovation governance framework, we have been able to show that, although current studies distinguish between social innovation processes and outputs (Nicholls and Dees, 2015), social innovation research has, thus far, not sufficiently considered the opportunity structures that trigger the emergence of such processes.

\subsubsection{What instruments enable social innovations?}

The social innovations that have established infrastructure in the rural areas investigated here have been influenced by instruments such as policies. For instance, the energy cooperatives studied were mostly initiated under the Renewable Energy Sources Act, which allowed local action groups to participate in energy-system transformation. Land.Zukunft and LEADER rural funding programmes of the German and EU governments - were also mentioned in several cases as incentive for social innovation. Case 3, for example, reported that the initiative was conceived because several citizens happened to meet at an information event held by a funding programme. Even if this is only one instance, it shows that social innovation can be triggered by top-down policies. Indeed, we found that almost all of the studied community cooperatives depend on public funds, which is supported by the study results of Lang and Roessl (2011) and Defourny and Nyssens (2016), emphasising the ability of social enterprises to accumulate various financial resources, which has not yet been linked sufficiently to the 
social innovation context. This link is interesting because social innovation researchers have questioned whether there can and should be instruments set in place for triggering social innovation. Neumeier (2017), for example, doubts the effectiveness of top-down methods for promoting social innovation processes, due to the endogenous character of social innovation, and Bock (2016) asks whether the promotion of social innovations is not just an attempt by politicians to assign tasks to civil society that should actually be assumed by the state.

In addition to political instruments, Borrás and Edler (2014) mention the existence of social instruments, which are dependent on who introduces them. We argue that community cooperatives embody a social instrument that can be used by capable actors to promote social or environmental goals in their communities. Previously, private- and public-sector actors had been performing services to maintain a certain quality of life in rural municipalities, but have recently been failing to properly deliver such services, creating new markets for different forms of organisation, such as community cooperatives (Table 1 and 3). In most cases, respondents opined that cooperatives are more efficient than their local government. They were also said to have more knowledge, because they include people from different backgrounds, with different specialised capacities when it comes to social, human and financial resources and time, jointly working for one goal. Thus, the community cooperative is seen as an instrument employed by the initiators to achieve social innovation processes at the local level. It combines formalisation of collective action, which makes it possible to do business, provides an identity to involved actors, and embodies a democratic system in the community.

\subsubsection{How are social innovation processes legitimised?}

Our results suggest that private actors seem to initiate projects that address not only the social or environmental needs of the community but also individual needs. On the one hand, such 
behaviour might be difficult to legitimise because one member of the community benefits more than others, while, on the other hand, it might be legitimisable because the private actor takes more risk than other cooperative members who voluntarily provides their human capital while having other sources of income. If we focus on collective action, as shown in Figure $2 b$ compared to $2 \mathrm{c}$, it can also be argued that private actors rely on financial resources provided by civil society and the public sector. However, this indicates that they must earn and maintain public trust, which can be seen as a legitimising mechanism while, at the same time, perhaps steering private actors away from opportunism through the democratic control mechanisms of the cooperative.

Similar to Richter (2018), our findings suggest that social enterprises such as community cooperatives are capable of "develop[ing] innovative solution[s] to social challenges". However, by investigating the whole social innovation process, we have found that most of the time idea generation occurs prior to the foundation of a community cooperative. As Neumeier (2017) and Lorendahl (1996) have indicated, most of the time there is a small active group of people developing a concept for social innovation who then depend upon others to evaluate, improve and legitimise their project idea. Hence, our findings suggest that, next to such active participants, passive membership is also important, such as those who support projects by just being members and contributing financial capital, showing support for their community. This support group was considered essential, primarily because most projects required a certain number of members and capital to get in gear. Thus, the founding event of a cooperative was not just another step but, rather, was described as a very emotional process, which was decisive for its success. Second, such actors can fulfil a need for legitimation from their community by joining its cooperative, which implies they trust that the core group can do a good job, which was also reported as motivating and instilling a sense of duty to move 
on with the next stage. Respondents often reported that they felt overwhelmed when they realised just how committed people were to their project.

\section{Conclusions}

The declining public infrastructure and quality of life in many rural areas is challenging the national innovation policies of many European and non-European countries. We have argued that the pursuit of economic growth, patents and scientific output at the national level leads to neglect of rural regions. As one possible solution to this problem, the concept of social innovation, due to its focus on collective action and the output of social goods, may be able to close this gap by enabling identification and promotion of innovative processes in rural areas that can maintain or establish new infrastructure.

To facilitate the identification and investigation of such innovative processes, we have introduced the governance of change framework, established by Borrás and Edler (2014) within the social-technical literature, and applied it as an analytical framework for the study of social innovation governance. Supported by its three pillars (1. agent and opportunity structure, 2. instruments, 3. legitimacy), we have formulated research questions for our empirical analysis, asking who and what enables social innovation processes in rural areas, how these processes are enabled and whether they are sufficiently legitimised.

Our investigation of actors capable of facilitating social innovation to solve the dilemmas of rural development has revealed that different types of social innovation processes are likely to be triggered by different opportunity structures. Those that maintain infrastructure often arise from local emergencies and seem to be initiated primarily by civil society actors. Meanwhile, those that build new infrastructure are driven by emerging public sector 
programmes, which appear to be initiated primarily by private actors who often also hold political positions in the community. While civil society entrepreneurs seem to be capable of initiating social innovation processes due to their social capital, the capabilities of private entrepreneurs can generally be attributed to their own economic incentives and the human capital they can offer a project. However, both processes show that the success of social innovation usually involves collective action between private, public and civil actors. These findings show how important it is to distinguish between various opportunity structures when considering rural innovation policy, which we recommend should be combined with social innovation policy in the future.

Regarding the question of what kinds of instruments can best promote social innovation in rural areas, we have found that rural actors are capable of using public funds for their own purposes, which has been doubted by some authors. Rural entrepreneurs also create their own instruments, which Boras and Edler consider to be social instruments, such as in our case establishment of community cooperatives. In most cases studied here, social entrepreneurs already had an idea, but they were dependent on the trust and money of the community to continue their project. In this context, community cooperatives not only serve as an instrument for formalised collective action but tend to legitimise this action and curb the opportunism of private entrepreneurs.

Some limitations should be noted. Although our proposed framework seems generally suitable for our chosen context, we are aware that this article represents only initial steps in this direction. Each of the pillars need to be developed further with reference to rural contexts and already have been discussed in similar contexts, such as Richter (2018) focusing on participatory governance and Huybrechts and Mertens (2014) introducing different types of legitimacy within the social enterprise literature. In order to increase comparability, our study 
was limited to community cooperatives in Germany. However, in many countries there are now also legal foundations that allow or even promote the establishment of similarly operating social enterprises, so our results may be interesting for these areas. Furthermore, many social enterprises act similarly, and the study does not only look at governance within the cooperative but focuses on the whole community. Thus, the study also gains importance for countries without cooperative history and laws. Another point worth mentioning is that our study presents results from a large number of projects, but our explorative research approach does not allow for precise systematic comparison such as qualitative comparative analysis. In order to evaluate long-term innovation strategies in such rural areas, quantitative and mixed-method research is needed to verify the assumptions made in this paper.

Nevertheless, we feel that the results of this study have a number of important implications for future research and practice. First, the study underlines that researchers working within different areas should network more closely to learn from each other. This is especially true of Richter's (2018) appeal to make the topic of social innovation more prominent within the social enterprise literature. In addition, there should be more empirical research on social innovation in rural areas, as it can be assumed that urban enterprises can also learn from these mechanisms. A key insight from our study is that public support for rural development should be decoupled from national innovation policies, as existing instruments have been generally ineffective and hard for actors to access. New efforts towards bolstering rural development should distinguish between different social innovation dynamics, critically examine the benefits for each community and, in any case, be more flexible and accessible for public actors as well as for private and civil society actors. 


\section{References}

Bauwens, T. and Defourny, J. (2017), "Social Capital and Mutual Versus Public Benefit: the Case of Renewable Energy Cooperatives", Annals of Public and Cooperative

Economics, Vol. 88 No. 2, pp. 203-232.

BBSR (2019), “Siedlungsstrukturelle Kreistypen”, available at:

https://www.bbsr.bund.de/BBSR/DE/Raumbeobachtung/Raumabgrenzungen/deutschlan d/kreise/Kreistypen4/kreistypen_node.html;jsessionid=976C2A5D038C376A42EB9A29 BA2B410C.live11293 (accessed 21 November 2019).

Beetz, S. (2008), "Peripherisierung als räumliche Organisation sozialer Ungleichheit”, in Barlösius, E. and Neu, C. (Eds.), Peripherisierung - eine neue Form sozialer Ungleichheit?, Berlin, pp. 7-16.

Birchall, J. and Simmons, R. (2009), Cooperatives and poverty reduction: Evidence from Sri Lanka and Tanzania, The Cooperative College, Manchester.

Bock, B. (2012), "Social innovation and sustainability; how to disentangle the buzzword and its application in the field of agriculture and rural development”, Studies in Agricultural Economics, Vol. 114 No. 2, pp. 57-63.

Bock, B. (2016), "Rural Marginalisation and the Role of Social Innovation; A Turn Towards Nexogenous Development and Rural Reconnection”, Sociologia Ruralis, Vol. 56 No. 4, pp. 552-573.

Bonus, H. (1986), “The Cooperative Association as a Business Enterprise: A Study in the Economics of Transactions", Journal of Institutional and Theoretical Economics, Vol. 142 No. 2, pp. 310-339.

Borrás, S. and Edler, J. (2014), "The governance of change in socio-technical and innovation systems: three pillars for a conceptual framework", in Borrás, S. and Edler, J. 
(Eds.), The Governance of Socio-Technical Systems: Explaining Change, Eu-SPRI

Forum on Science, Technology and Innovation Policy series, Edward Elgar Publishing, Cheltenham, pp. 23-48.

Borzaga, C. and Bodini, R. (2012), "What to Make of Social Innovation? Towards a

Framework for Policy Development”, SSRN Electronic Journal.

Brunie, A. (2009), "Meaningful distinctions within a concept: relational, collective, and generalized social capital”, Social science research, Vol. 38 No. 2, pp. 251-265.

Butkevičienè, E. (2009), "Social innovations in rural communities: methodological framework and empirical evidence", Social Science/Socialiniai Mokslai, Vol. 63 No. 1, pp. $80-88$.

Copus, A. (2011), European Development Opportunities for Rural Areas: Final Report (accessed 24 October 2019).

Dargan, L. and Shucksmith, M. (2008), “LEADER and Innovation”, Sociologia Ruralis, Vol. 48 No. 3, pp. 274-291.

Defourny, J. and Nyssens, M. (2016), Fundamentals for an International Typology of Social Enterprise Models, ICSEM Working Papers, Liege (accessed 31 March 2020).

DGRV (2019), “Über uns”, available at: https://www.dgrv.de/de/ueberuns.html (accessed 6 December 2019).

DZ Bank (2017), Die deutschen Genossenschaften 2017. Entwicklungen - Meinungen Zahlen, Wiesbaden.

Eder, J. (2019), "Innovation in the Periphery: A Critical Survey and Research Agenda", International Regional Science Review, Vol. 42 No. 2, pp. 119-146.

Ehrlich, K., Kriszan, A. and Lang, T. (2012), "Urban Development in Central and Eastern Europe - Between Peripheralization and Centralization?”, disP - The Planning Review, Vol. 48 No. 2, pp. 77-92.

EU (2014), Social innovation: A decade of changes, Luxembourg. 
EU (2019), “Social Innovation", available at:

https://ec.europa.eu/growth/industry/innovation/policy/social_en (accessed 21 November 2019).

Figueiredo, V. and Franco, M. (2018), "Wine cooperatives as a form of social entrepreneurship: Empirical evidence about their impact on society”, Land Use Policy, Vol. 79, pp. 812-821.

Flick, U. (2017), Qualitative Sozialforschung: Eine Einführung, Rororo Rowohlts Enzyklopädie, Vol. 55694, Originalausgabe, 8. Auflage, rowohlts enzyklopädie im Rowohlt Taschenbuch Verlag, Reinbek bei Hamburg.

Hanisch, M. and Fairbairn, B. (2017), German energy co-operatives as agents of social innovation.

Haunstein, S. and Thürling, M. (2017), Aktueller Gründungsboom - Genossenschaften liegen im Trend, 11 (accessed 6 December 2019).

Hollanders, H., Es-Sadki, N. and Merkelbach, I. (2019), Regional Innovation Scoreboard 2019: Methodology Report, available at: https://ec.europa.eu/docsroom/documents/37783 (accessed 21 November 2019).

Howaldt, J. and Schwarz, M. (2010), “Soziale Innovation - Konzepte, Forschungsfelder und -perspektiven", in Howaldt, J. (Ed.), Soziale Innovation: Auf dem Weg zu einem postindustriellen Innovationsprardigma, Vol. 49, VS Verlag für Sozialwissenschaften, Wiesbaden, pp. 87-108.

Huybrechts, B. and Mertens, S. (2014), "The relevance of the cooperative model in the field of renewable energy", Annals of Public and Cooperative Economics, Vol. 85 No. 2, pp. $193-212$.

ICA (2019), "Cooperative identity, values \& principles | ICA”, available at: https://www.ica.coop/en/cooperatives/cooperative-identity (accessed 24 October 2019). 
Keim, K.-D. (2006), “Peripherisierung ländlicher Räume”, Aus Politik und Zeitgeschichte, Vol. 11 No. 37, pp. 3-7.

Kluth, W. (2019), "Bürgerbeteiligung neu denken. Die Genossenschaft als Weg aus der Krise der Demokratie", Frankfurter Allgemeine Zeitung, 19 June (accessed 3 December 2019).

Kozłowski, J. (2015), "Innovation indices: the need for positioning them where they properly belong”, Scientometrics, Vol. 104 No. 3, pp. 609-628.

Lang, R. and Roessl, D. (2011), "Contextualizing the Governance of Community Cooperatives: Evidence from Austria and Germany", VOLUNTAS: International Journal of Voluntary and Nonprofit Organizations, Vol. 22 No. 4, pp. 706-730.

Lang, T. (2012), "Shrinkage, Metropolization and Peripheralization in East Germany", European Planning Studies, Vol. 20 No. 10, pp. 1747-1754.

Lorendahl, B. (1996), "New Cooperatives and Local Development: A Study of Six Cases in J imtland, Sweden”, Journal of Rural Studies, Vol. 12 No. 2, 143-150.

Marques, P., Morgan, K. and Richardson, R. (2018), "Social innovation in question: The theoretical and practical implications of a contested concept", Environment and Planning C: Politics and Space, Vol. 36 No. 3, pp. 496-512.

Mazzei, M. (2017), 'Understanding Difference: The Importance of 'Place' in the Shaping of Local Social Economies”, VOLUNTAS: International Journal of Voluntary and Nonprofit Organizations, Vol. 28 No. 6, pp. 2763-2784.

Moulaert, F. and Sekia, F. (2003), “Territorial Innovation Models: A Critical Survey”, Regional Studies, Vol. 37 No. 3, pp. 289-302.

Mulgan, G. (2006), “The process of social innovation”, Innovations: technology, governance, globalization, Vol. 1 No. 2, pp. 145-162.

Mumford, M.D. (2002), “Social Innovation: Ten Cases From Benjamin Franklin”, Creativity Research Journal, Vol. 14 No. 2, pp. 253-266. 
Münkner, H. (2012), Co-operation as a Remedy in Times of Crisis. Agricultural Cooperatives in the World. Their Roles for Rural Development and Poverty Reduction (accessed 18 November 2019).

Murray, R., Caulier-Grice, J. and Mulgan, G. (2010), The Open Book on Social Innovation, Social Innovation Serries: Ways to design, develop and grow social innovaiton, UK.

Neumeier, S. (2012), "Why do Social Innovations in Rural Development Matter and Should They be Considered More Seriously in Rural Development Research? - Proposal for a Stronger Focus on Social Innovations in Rural Development Research”, Sociologia Ruralis, Vol. 52 No. 1, pp. 48-69.

Neumeier, S. (2017), "Social innovation in rural development: identifying the key factors of success", The Geographical Journal, Vol. 183 No. 1, pp. 34-46.

Nicholls, A. and Dees, J.G. (2015), “Social Innovation”, in Wright, J.D. (Ed.), International encyclopedia of the social \& behavioral sciences, Second edition, Elsevier; Elsevier Science, Amsterdam, Netherlands, Burlington, pp. 355-361.

Noack, A. and Federwisch, T. (2019), "Social Innovation in Rural Regions: Urban Impulses and Cross-Border Constellations of Actors”, Sociologia Ruralis, Vol. 59 No. 1, pp. 92 112.

OECD (2014), Innovation and Modernising the Rural Economy, OECD Publishing. Phillips, W., Lee, H., Ghobadian, A., O’Regan, N. and James, P. (2015), “Social Innovation and Social Entrepreneurship”, Group \& Organization Management, Vol. 40 No. 3, pp. $428-461$.

Pol, E. and Ville, S. (2009), "Social innovation: Buzz word or enduring term?”, The Journal of Socio-Economics, Vol. 38 No. 6, pp. 878-885.

Richter, R. (2018), “The Janus face of participatory governance: How inclusive governance benefits and limits the social innovativeness of social enterprises", The Journal of Entrepreneurial and Organizational Diversity, Vol. 7 No. 1, pp. 61-87. 
Rodriguez-Pose, A. and Di Cataldo, M. (2015), "Quality of government and innovative performance in the regions of Europe", Journal of Economic Geography, Vol. 15 No. 4, pp. 673-706.

Schultz, T. (1961), "Investment in Human Capital”, The American Economic Review, Vol. 51 No. 1, pp. 1-17.

Schumpeter, J. (1934), The theory of economic development;: An inquiry into profits, capital, credit, interest, and the business cycle, Harvard economic studies, vol. XLVI, Harvard University Press, Cambridge, Mass.

Shearmur, R. (2012), "Are cities the font of innovation? A critical review of the literature on cities and innovation", Cities, Vol. 29, S9-S18.

Shearmur, R.G., Carrincazeaux, C. and Doloreux, D. (2018), Handbook on the geographies of innovation, Paperback edition, Edward Elgar Publishing, Cheltenham, UK, Northampton, MA.

Somerville, P. (2007), “Co-operative Identity”, Defourny and Nyssens, Vol. 40 No. 1, Defourny and Nyssens.

Somerville, P. and McElwee, G. (2011), "Situating community enterprise: A theoretical exploration”, Entrepreneurship \& Regional Development, Vol. 23 No. 5-6, pp. 317-330.

Steiner, A. and Farmer, J. (2018), “Engage, participate, empower: Modelling power transfer in disadvantaged rural communities", Environment and Planning C: Politics and Space, Vol. 36 No. 1, pp. 118-138.

Steiner, A. and Teasdale, S. (2019), "Unlocking the potential of rural social enterprise", Journal of Rural Studies, Vol. 70, pp. 144-154.

Storey, R. (1980), “Community co-operatives - a Highlands and Islands experiment.”, in MacKone, C.E. and Basar, H. (Eds.), Year book of agricultural co-operation 1979, The Plunkett Foundation for Co-operative Studies [etc.], Oxford, pp. 89-104. 
Thürling, M. (2019), “Zur Gründung von gemeinwesenorientierten Genossenschaften”, Zeitschrift für das gesamte Genossenschaftswesen, Vol. 69 No. 2, pp. 85-116. van der Have, R.P. and Rubalcaba, L. (2016), "Social innovation research: An emerging area of innovation studies?”, Research Policy, Vol. 45 No. 9, pp. 1923-1935. Wieg, A. (2014), “Krisenerprobung und Krisenresistenz des genossenschaftlichen Ordnungsmodells”, in Bauer, H., Büchner, C. and Markmann, F. (Eds.), Kommunen, Bürger und Wirtschaft im solidarischen Miteinander von Genossenschaften, KWI Schriften, Univ.-Verl., Potsdam, pp. 23-32. 


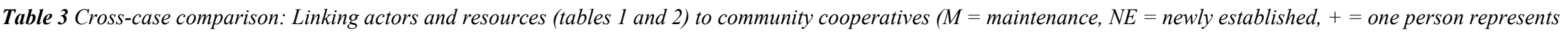
several sectors)

\begin{tabular}{|c|c|c|c|c|c|}
\hline No. & Description & Driver of social innovation & Process initiation & Human and Social capital & Financial capital \\
\hline 1 & $\begin{array}{l}\text { Community } \\
\text { centre, village } \\
\text { shop (M) }\end{array}$ & $\begin{array}{l}\text { Demand: owner died, dilapidated } \\
\text { building for sale, last pub in village, } \\
\text { fear of conversion }\end{array}$ & $\begin{array}{l}\text { Civil Society (Head of } \\
\text { community club, retired) }\end{array}$ & $\begin{array}{l}\text { Public sector (recommended } \\
\text { information event, mayor shared } \\
\text { his network) } \\
\text { Civil society (group of experts) }\end{array}$ & $\begin{array}{l}\text { Civil society(membership fees, rent) } \\
\text { Private sector (bank loan, membership fees) } \\
\text { Public Sector (municipality,LEADER) }\end{array}$ \\
\hline 2 & $\begin{array}{l}\text { Community } \\
\text { house, hotel } \\
\text { (M) }\end{array}$ & $\begin{array}{l}\text { Demand (owner died, building for } \\
\text { sale, offer made for hotel, fear of } \\
\text { losing cultural meeting place) }\end{array}$ & $\begin{array}{l}\text { Civil Society }+ \text { Public Sector } \\
\text { (Member of local and regional } \\
\text { government }+ \text { personal } \\
\text { history) }\end{array}$ & $\begin{array}{l}\text { Public sector (shared network, } \\
\text { LEADER application) } \\
\text { Civil society (experts, circle of } \\
\text { friends and supporter) }\end{array}$ & $\begin{array}{l}\text { Civil Society (membership fees, rent) } \\
\text { Private Sector (membership fee, bank loan) } \\
\text { Public Sector (LEADER, municipality) }\end{array}$ \\
\hline 3 & $\begin{array}{l}\text { Community } \\
\text { house, café } \\
(\mathrm{NE})\end{array}$ & $\begin{array}{l}\text { Opportunity (local newspaper } \\
\text { article about informational event } \\
\text { regarding national funding project } \\
\text { Land.Zukunft) }\end{array}$ & $\begin{array}{l}\text { Civil society (people from } \\
\text { municipality that coincidently } \\
\text { met at information event) }\end{array}$ & $\begin{array}{l}\text { Civil society (Core group of } \\
\text { experts with network) } \\
\text { Private sector (use of public } \\
\text { funds for the maintenance of a } \\
\text { building for the cooperative) }\end{array}$ & $\begin{array}{l}\text { Civil society (membership fees, café } \\
\text { income) } \\
\text { Public sector (funding programme for } \\
\text { investor) }\end{array}$ \\
\hline 4 & $\begin{array}{l}\text { Community } \\
\text { swimming pool } \\
\text { (M) }\end{array}$ & $\begin{array}{l}\text { Demand for social innovation } \\
\text { (municipality had to close } \\
\text { swimming pool, people wanted to } \\
\text { swim) }\end{array}$ & $\begin{array}{l}\text { Civil society (people strongly } \\
\text { connected to swimming pool) }\end{array}$ & $\begin{array}{l}\text { Public sector (support due to } \\
\text { school swimming by the district } \\
\text { government) } \\
\text { Civil society (expert group and } \\
\text { supporters) }\end{array}$ & $\begin{array}{l}\text { Civil Society (membership fees) } \\
\text { Private Sector (membership fees, bank } \\
\text { loan) } \\
\text { Public Sector (EU funds, national funds, } \\
\text { municipal funds) }\end{array}$ \\
\hline 5 & $\begin{array}{l}\text { Community } \\
\text { swimming pool } \\
\text { (M) }\end{array}$ & $\begin{array}{l}\text { Demand for social innovation } \\
\text { (municipality had to close } \\
\text { swimming pool, citizens wanted } \\
\text { place where children could learn to } \\
\text { swim) }\end{array}$ & $\begin{array}{l}\text { Civil society } \\
\text { (Head of swimming club) }\end{array}$ & $\begin{array}{l}\text { Civil Society (expert group and } \\
\text { supporters) }\end{array}$ & $\begin{array}{l}\text { Civil Society (membership and entry fees, } \\
\text { donations) } \\
\text { Private Sector (membership fees, } \\
\text { donations, regional foundations) } \\
\text { Public Sector (municipal funds) }\end{array}$ \\
\hline 6 & $\begin{array}{l}\text { Elderly care, } \\
\text { community } \\
\text { house } \\
(\mathrm{NE})\end{array}$ & $\begin{array}{l}\text { Opportunity for social innovation } \\
\text { (Fire ruined centre of village, } \\
\text { Land.Zukunft funding programme, } \\
\text { need for new nursing home) }\end{array}$ & $\begin{array}{l}\text { Private sector }+ \text { Public sector } \\
\text { (Deputy mayor and director of } \\
\text { nursing home) }\end{array}$ & $\begin{array}{l}\text { Private Sector (entrepreneurial } \\
\text { knowledge, external architect) } \\
\text { Public Sector } \\
\text { (trust and network) }\end{array}$ & $\begin{array}{l}\text { Public Sector (membership fees, loans, tax } \\
\text { money for renewable energies from } \\
\text { neighbouring villages, Land.Zukunft } \\
\text { support programme) } \\
\text { Private Sector (bank loan, membership } \\
\text { fees) } \\
\text { Civil Society (membership fees) }\end{array}$ \\
\hline
\end{tabular}




\begin{tabular}{|c|c|c|c|c|c|}
\hline 7 & $\begin{array}{l}\text { E-mobility } \\
\text { (NE) }\end{array}$ & $\begin{array}{l}\text { Opportunity for social innovation } \\
\text { (regional event for renewable } \\
\text { energy, on-site use of renewable } \\
\text { energy) }\end{array}$ & $\begin{array}{l}\text { Private Sector (actors from } \\
\text { renewable energies) }\end{array}$ & $\begin{array}{l}\text { Private Sector (networking, } \\
\text { consulting, selling e-cars) }\end{array}$ & $\begin{array}{l}\text { Private sector (membership fees) } \\
\text { Public sector (taxpayer money from } \\
\text { renewable energy production) } \\
\text { Civil society (membership fees) }\end{array}$ \\
\hline 8 & $\begin{array}{l}\text { E-mobility } \\
\text { (NE) }\end{array}$ & $\begin{array}{l}\text { Opportunity for social innovation } \\
\text { (desire to support regional } \\
\text { development, met important } \\
\text { politician at right time) }\end{array}$ & $\begin{array}{l}\text { Civil Society (two young } \\
\text { people initiated exhibition and } \\
\text { met like-minded people) }\end{array}$ & $\begin{array}{l}\text { Civil Society (built up a network, } \\
\text { continued to educate themselves) }\end{array}$ & $\begin{array}{l}\text { Civil society (membership fees) } \\
\text { Private sector (membership fees, joint } \\
\text { investment, bank credit) } \\
\text { Public sector (LEADER, EFRE) }\end{array}$ \\
\hline 9 & $\begin{array}{l}\text { Freshwater } \\
\text { supply } \\
\text { (M) }\end{array}$ & $\begin{array}{l}\text { Demand for social innovation } \\
\text { (public water network to be sold, } \\
\text { fear of decreasing water quality and } \\
\text { increasing prices) }\end{array}$ & $\begin{array}{l}\text { Civil Society (committed local } \\
\text { citizen) }\end{array}$ & Civil Society (expert group) & $\begin{array}{l}\text { Civil society (membership fees, connection } \\
\text { costs) } \\
\text { Public sector (outstanding investments, } \\
\text { public funds) }\end{array}$ \\
\hline 10 & $\begin{array}{l}\text { Local heating } \\
\text { grid, power } \\
\text { plant (NE) }\end{array}$ & $\begin{array}{l}\text { Opportunity for social innovation } \\
\text { (private biogas plant with excess } \\
\text { heat) }\end{array}$ & $\begin{array}{l}\text { Public }+ \text { Private Sector } \\
\text { (mayor and owner of biogas } \\
\text { plant) }\end{array}$ & $\begin{array}{l}\text { Civil Society (regional } \\
\text { bioenergetic villages network) } \\
\text { Private sector (expert knowledge) }\end{array}$ & $\begin{array}{l}\text { Civil society (membership fees, connection } \\
\text { costs) } \\
\text { Public sector (regional government, public } \\
\text { bank loan) }\end{array}$ \\
\hline 11 & $\begin{array}{l}\text { Local heating } \\
\text { grid, power } \\
\text { plant (NE) }\end{array}$ & $\begin{array}{l}\text { Opportunity for social innovation } \\
\text { (two private biogas plants) }\end{array}$ & $\begin{array}{l}\text { Public sector (major), } \\
\text { Private sector (head of local } \\
\text { bank) }\end{array}$ & $\begin{array}{l}\text { Public Sector (trust and network) } \\
\text { Private Sector (technical } \\
\text { expertise) }\end{array}$ & $\begin{array}{l}\text { Civil society (membership fees, connection } \\
\text { costs) } \\
\text { Private sector (bank loan) } \\
\text { Public sector (funding projects) }\end{array}$ \\
\hline 12 & $\begin{array}{l}\text { Multi- } \\
\text { generation } \\
\text { housing (NE) }\end{array}$ & $\begin{array}{l}\text { Opportunity for social innovation } \\
\text { (free feasibility study) }\end{array}$ & $\begin{array}{l}\text { Civil society (local } \\
\text { environmental initiative) }\end{array}$ & $\begin{array}{l}\text { Private sector (external project } \\
\text { manager) } \\
\text { Civil society (core groups of } \\
\text { experts) }\end{array}$ & $\begin{array}{l}\text { Civil society (membership fees, rent) } \\
\text { Private sector (donations, co-ownership) } \\
\text { Public sector (promotional programmes, } \\
\text { bank loans) }\end{array}$ \\
\hline 13 & $\begin{array}{l}\text { Photovoltaics } \\
\text { (NE) }\end{array}$ & $\begin{array}{l}\text { Opportunity for social innovation } \\
\text { (local climate goals, desire to } \\
\text { participate). }\end{array}$ & $\begin{array}{l}\text { Public sector + Private sector } \\
\text { (local government member }+ \\
\text { renewable-energy system } \\
\text { planner) }\end{array}$ & $\begin{array}{l}\text { Private Sector (expert) } \\
\text { Civil Society (core groups of } \\
\text { experts) }\end{array}$ & $\begin{array}{l}\text { Civil Society (membership fees) } \\
\text { Public Sector (membership fees, bank loan) } \\
\text { Public Sector (funding, membership fees) }\end{array}$ \\
\hline 14 & $\begin{array}{l}\text { Wind power } \\
\text { (NE) }\end{array}$ & $\begin{array}{l}\text { Opportunity for social innovation } \\
\text { (state politician looking for pilot } \\
\text { project) }\end{array}$ & $\begin{array}{l}\text { Civil society (retired, former } \\
\text { head of local bank, founder of } \\
\text { photovoltaics cooperative) }\end{array}$ & $\begin{array}{l}\text { Private Sector (wind plant } \\
\text { company) } \\
\text { Civil society (core groups of } \\
\text { experts) }\end{array}$ & $\begin{array}{l}\text { Civil society (membership fees) } \\
\text { Public Sector (bank loan, funding) }\end{array}$ \\
\hline
\end{tabular}

